\title{
ТЕОРЕТИЧНІ ПІДХОДИ ДО ТРАКТУВАННЯ ПРИНЦИПІВ ФІНАНСІВ ГРОМАДЯНСЬКОГО СУСПІЛЬСТВА
}

\author{
THEORETICAL APPROACHES TO THE INTERPRETATION \\ OF THE PRINCIPLES OF THE CIVIL SOCIETY FINANCES
}

Ткачук І. Я.

д.е.н., доцент, доцент кафедри фрінансів і кредиту, Чернівецький національний університет імені Юрія Федьковича

ORCID ID: 0000-0003-1081-8693

\begin{abstract}
Iryna Tkachuk
Doctor of Economic Sciences, Associate Professor, Associate Professor of Finance and Credit Department, Yuriy Fedkovych Chernivtsi National University
\end{abstract}

У статmі висвітлено характерні ознаки організації фрінансів інститутів громадянського суспільства, що визначають їх особливості у порівнянні із фрінансами комерційних установ. Здійснено аналіз основних підходів до трактування принципів функіонування та організації фрінансів громадянського суспільства у працях науковців, на підставі якого визначено 11 основних принципів, об'єднаних в 3 основні змістовно відмінні групи: 1) безпосередньо стосуються особливостей діяльності неурядових організацій порівняно з комерційними організаціями; 2) пов'язані із процесом фрормування та використання фрінансових ресурсів та контролю за ним; 3) відображають особливості організації фрінансів громадянського суспільства відповідно до вимог сучасності. Завдяки такому поділу можна дослідити особливості функціонування фрінансів громадянського суспільства відповідно до основних змістових характеристик, а також ролей (реальної чи потенційної), які вони відіграють у суспільстві та економіці. Ключові слова: фрінанси, організація фрінансів, фінанси громадянського суспільства, неурядові організації, принципи фрінансів неурядових організацій.

В статье отражены характерные признаки организации фринансов институтов гражданского общества, определяющие их особенности по сравнению с финансами коммерческих учреждений. Осуществлен анализ основных подходов к трактовке принципов функционирования и организации фринансов гражданского общества в трудах ученых, на основании которого определено 11 основных принципов, объединенных в 3 основные содержательно отличные группы: 1) непосредственно касаются особенностей деятельности неправительственных организаций по сравнению с коммерческими организациями; 2) связанные с процессом формирования и использования фринансовых ресурсов и контроля за ним; 3) отражают особенности организации фринансов гражданского общества в соответствии с требованиями XX века. Благодаря такому разделу можно исследовать особенности фрункционирования финансов гражданского общества в соответствии с основными содержательными характеристиками, а также ролями (реальной или потенциальной), которые они играют в обществе и экономике. Ключевые слова: фринансы, фринансы организация фринансов, фринансы гражданского общества, неправительственные организации, принципы финансов неправительственных организаций.

The article highlights the characteristics of the organization of finances of civil society institutions, which determine their features in comparison with the finances of commercial institutions. An analysis of the main approaches to the interpretation of the principles of functioning and organization of civil society finances in the works of scientists was made. Based on it 11 basic principles are identified, wich are grouped into 3 main substantively different groups: 1) directly related to the activities of non-governmental organizations; 2) related to the process of formation and use of financial resources and control over it; 3) reflect the peculiarities of the organization of civil society finances in accordance with modern requirements. Such an approach make it possible to explore the features of the functioning of civil society finances in accordance with the main semantic characteristics, as well as the roles (real or potential) that they play in society and the economy. This division of principles of organization and functioning of civil society finances allows the researcher to form a theoretical basis for studying the peculiarities of their functioning in accordance with the main semantic characteristics, as well as the role they play or can play in society. As a result of critical analysis of approaches to the interpretation of the principles of organization and functioning of civil society finances, their financial aspects, as well as theoretical approaches to determining the principles of non-governmental organizations, the basic principles of organization and functioning of civil society finances. It is noted that in order to build a methodology for studying the finances of civil society, it is necessary to carry out a critical analysis of theoretical and practical approach- 
es to the interpretation of the basic principles of organization, functioning and financing of civil society institutions. Key words: finances, organization of finances, civil society finances, non-governmental organizations, principles of non-governmental organizations finances.

Постановка проблеми. Вивчення будь-якого явища вимагає від науковця здійснення першочергового аналізу основ його функціонування. Це пов'язано з необхідністю з'ясування умов, у яких фрункціонує таке явище, визначення фракторів, що впливають на нього, а також тих процесів, що безпосередньо залежать від стану фрункціонування цього явища. Це особливо стосується і фрінансів громадянського суспільства, оскільки ІГС $\epsilon$ організаційно визначеними та фрункціонують у конкретних умовах, які впливають на фрормування, розподіл, перерозподіл і використання їхніх фінансових ресурсів. Тому в процесі побудови методології дослідження фрінансів громадянського суспільства потрібно здійснити критичний аналіз теоретичних та практичних підходів до трактування основних принципів організації, фрункціонування та фрінансування інститутів громадянського суспільства.

Аналіз останніх досліджень і публікацій. До питань створення та фрункціонування неурядових організацій зверталися у своїх дослідженнях численні науковці. Так, найбільш вагомим внеском у розробку цієї теми, на нашу думку, вирізняються праці таких зарубіжних вчених, як А. Круасан [1], М. Едвардс [2], Г. Лаут [3], В. Меркель [3], Т. Пафенгольц [4], К. Спарк [4], Дж. Шейд [5], а також українських - Л. Василенко [9], С. Зелінського [9], О. Віннікова [10], Н. Дехтяр [14], О. Люта [14], О. Кириленко [16], С. Обушного [19] та ін.

Водночас, з практичної сторони низкою організацій, що безпосередньо займаються дослідженням особливостей фрункціонування неурядових організацій (такими організаціями є: Круглий стіл Ко за моральний капіталізм (Caux Round Table for Moral Capitalism), Бюро демократії, прав людини і праці США (Bureau of Democracy, Human Rights, and Labor of USA), ОБСЄ й різні платформи НУО), було розроблено власні підходи до трактування принципів організації та функціонування інститутів громадянського суспільства. Раніше нами було вже проаналізовано їхні підходи до виділення принципів утворення та діяльності ІГС [6] та зроблено висновок про те, що спільними для цих організацій $є$ такі принципи фрункціонування і фрінансування інститутів громадянського суспільства, як добровільність створення; орієнтація на суспільну вигоду; співпраця з іншими суб'єктами для досягнення мети діяльності; підзвітність; рівність прав та свобод; правовий захист діяльності [6].

Виділення невирішених раніше частин загальної проблеми, котрим присвячується означена стаття. Не зважаючи на існуючі на- працювання, методологія дослідження фрінансів громадянського суспільства потребує глибокого аналізу наявних теоретичних підходів до трактування принципів фрінансів громадянського суспільства.

Формулювання цілей статті (постановка завдання). Метою дослідження є визначити принципи, що $є$ основними для організації та функціонування фрінансів громадянського суспільства.

Виклад основного матеріалу дослідження. Якщо у державах, що характеризуються розвиненістю економіки та високим рівнем демократії, дослідження, присвячені ІГС, носять практичний характер, а принципи, розроблені міжнародними організаціями, стосуються, в основному, особливостей їх організації та фрункціонування (хоча, зауважимо, що багато з цих принципів містять положення, що стосуються фрінансових аспектів функціонування ІГС), то на пострадянському просторі у наукових дослідженнях переважають ті, що присвячені їх теоретичним засадам. При цьому велика кількість досліджень, безпосередньо присвячена розкриттю теоретичних засад фрункціонування саме фрінансів ІГС, в тому числі і принципів їх організації.

Одна, перш ніж розглядати принципи фрінансів громадянского суспільства, висвітлимо особливості їх (фінансів громадянського суспільства) організації та фрункціонування.

Так, Н. В. Семенова зазначає, що особливе місце фрінансів неурядових організацій (НУО) у фрінансовій системі визначається тим положенням, яке вони займають у системі: держава бізнес - суспільство. Саме за рахунок некомерційного сектору створюється і підтримується соціальна рівновага, фрормується відповідальне ГС і надається широкий спектр соціальних послуг. Разом з державними фрінансами фрінанси НУО утворюють сферу публічних фрінансів, тобто фрінансів, відкритих для суспільного контролю.

Вона наголошує, що оскільки НО створюються для вирішення проблем, які неможливо вирішити лише комерційним структурам і органам влади, але, водночас, тісно взаємопов'язані 3 цими секторами економіки, варто виокремити такі особливості в організації їх фрінансів:

1. НУО не мають на меті отримання прибутку, а працюють для реалізації цілей, спрямованих на досягнення суспільних благ, закріплених в їх статуті.

2. НУО можуть здійснювати підприємницьку діяльність, фрормуючи частину своїх фрінансових ресурсів за рахунок самостійно зароблених коштів, які можуть бути витрачені виключно для 
реалізації статутних цілей. Використання грошей у господарському обігу дозволяє їм прискорити досягнення своїх цілей, забезпечити стабільність роботи, придбати необхідні ресурси.

Зазначені особливості визначають місце фінансів НУО як проміжне між державними фрінансами і фрінансами комерційних структур [21, С. 199-200].

На наш погляд, слушним для розуміння сутності організації фрінансів НУО, є виокремлювані згаданою дослідницею такі її особливості, як можливості здійснювати громадську діяльність з мінімальними фрінансовими витратами або без них, спираючись на ентузіазм і особисті переконання прихильників некомерційної організації, а також використання грошей у господарському обігу, що дозволяє прискорити досягнення НО своїх цілей, забезпечення стабільності роботи, придбання необхідних ресурсів.

Натомість Т. Ю. Кисельова акцентує увагу на тому, що, на відміну від комерційної організації, яка залучає зовнішні фрінансові ресурси лише в окремих випадках, НУО змушені постійно звертатися до засновників, членів, учасників, донорів для продовження своєї фрінансово-господарської діяльності [17, с. 9].

Крім того, НУО беруть участь у русі фрінансових потоків, перерозподілі грошових коштів між учасниками фрінансових відносин. До сектору НУО входять всі інституційні одиниці з надання неринкових послуг для колективного споживання. Особливості організації фрінансів НО як самостійних господарюючих суб'єктів визначаються цільовою спрямованістю статутної діяльності, порядком і джерелами ії фрінансування [13, с. 5860].

Розглядаючи особливості фрінансів НУО І. С. Гаркавенко акцентує увагу, насамперед, на спрямованості руху грошових коштів, характері відносин НО, формуванні фрондів.

На його думку, характерними ознаками фрінансів НО є [11, С. 84-85]:

1) односпрямованість руху грошових коштів, тобто рух мобілізованих грошей не залежить від товарних потоків;

2) перерозподільний характер відносин, зумовлений вторинним розподілом уже розподіленого ВВП;

3) формування централізованих і децентралізованих фондів грошових коштів для створення суспільних благ, благодійності, колективного споживання.

Поряд з цим, до особливостей фрінансів НУО І. С. Гаркавенко відносить і те, що, оскільки їх активи не призначені для отримання прибутку і їх не можна розглядати як капітал, є суттєва відмінність в обігу коштів, що здатне вплинути на фрінансове управління ними. Так, НУО, що займаються благодійністю, не розраховують на еквівалентність відносин благодійника (донора) і благоодержувача [11, с. 87].

Відтак, трансферти (витрати) НУО можуть перевищувати надходження (доходи), а ціни виробництва суспільних благ бути нижче ринкових. Цільові вкладення коштів НО часто не можуть розглядатися як інвестиції, накопичення капіталу.

На особливостях фрінансової стійкості НУО зупиняється в своїх працях Т. Ю. Кисельова. Так, вона вважає, що фрінансова стійкість НУО відрізняється від фрінансової стійкості комерційної організації. НУО обмежена у можливостях залучення фрінансових ресурсів за рахунок операцій на фрінансовому ринку. Поняття банкрутства рідко до неї застосовується. Проблема забезпечення фінансової стійкості НУО пов'язана з пошуком необхідних фрінансових ресурсів, достатніх для компенсації майбутніх витрат на виробництво суспільного блага. Водночас, для НУО, як і для комерційної, фрінансова стійкість повинна мати довгостроковий характер. Якщо залучені надходження швидко вичерпуються, то і фрінансова стійкість носить скороминучий характер. Говорити про фрінансову стійкість НУО можна, якщо надходжень вистачає для компенсації витрат упродовж тривалого періоду (від трьох до п'яти років). Ведення діяльності, що приносить доходи, не ставить проблему фрінансової стійкості у загальноприйнятому розумінні, позаяк допуск до кредитних ресурсів для НО обмежений $[17$, c. 50$]$.

Особливе місце у фінансах НУО належить їх фрінансовому механізму. Так, С. В. Фрумина, Т. Ю. Киселева, С. С. Дзусова наголошують, що з погляду змістовної частини багато елементів фрінансового механізму НУО будуть зовнішньо схожими з елементами фрінансового механізму комерційної організації. Але характер діяльності і особливості формування й розподілу фрінансових ресурсів НУО будуть тими умовами, внаслідок яких фрінансовий механізм НУО набуває самостійності, автономності від фрінансового механізму комерційної організації. Зазначені дослідниці підкреслюють, що фінансовий механізм $€$ інструментом реалізації фрінансової політики НУО, і вид фрінансових відносин може безпосередньо впливати на їх фрінансову стійкість. Відтак, при фрормуванні фрінансового механізму необхідно особливу увагу приділити вибору джерел фрінансування і видам фрінансових ресурсов $[24$, c. 64,66$]$.

Розглянемо детальніше основні підходи до трактування принципів фрінансів ІГС (фрінансів ГС). Так, О. В. Грищенко в процесі дослідження механізму формування фрінансових ресурсів некомерційних організацій зазначає, що їх фрінанси 
ґрунтуються на семи основних принципах. Такими принципами, на думку автора, є [12, с. 65]:

- зовнішнє фінансування, до якого відносяться членські внески, пожертви, гранти, благодійна допомога, бюджетні кошти, внески на формування цільового капіталу;

- цільовий характер використання грошових засобів;

- відсутність прибутку і окупності;

- відкритість фінансів і громадський контроль;

- підзвітність особі-джерелу фінансування;

- соціальна спрямованість діяльності;

- соціальна відповідальність некомерційних організацій.

Схожого підходу дотримується також Л. Б. Балкоєва, яка дослідила особливості організації фінансів ГС, в результаті чого виділила основні принципи організації фінансових відносин некомерційних організацій. Дослідниця, поряд із такими спільними з підходом О. В. Грищенка принципами, як фінансування за рахунок зовнішніх джерел (до таких джерел науковиця відносить членські внески, гранти, пожертвування, субсидії, благодійну допомогу); відсутність прибутків та самоокупності; відкритість господарської діяльності, громадський контроль, відсутність комерційної таємниці; підзвітність по відношенню до джерела фінансування; використання грошових коштів відповідно до кошторису організацій (цільове використання фінансових ресурсів), виділила ще такі, як провадження діяльності відповідно до установчих документів, реалізація суспільних інтересів та відповідальність учасників організації за її діяльність. [7, с. 53].

Натомість І. В. Ішина та О. Доліна доповнюють зазначений перелік таким специфічним принципом, як витратність, що зумовлює збитковість діяльності НО та відсутність самоокупності [15,c. 157-160].

Частково погоджуємося із викладеним науковцями підходом до виділення принципів фінансів НУО, однак хочемо зауважити, що деякі принципи не $є$ практично застосовними, адже вони певною мірою суперечать особливостям їх функціонування на сучасному етапі розвитку економіки та ГС. Так, ми не поділяємо думку науковців з приводу віднесення членських внесків до зовнішніх джерел фінансування. Вважаємо, що ці надходження НУО є внутрішніми відносно до самої організації, оскільки вони надходять не просто від осіб, що поділяють мету діяльності організації, а від осіб, які безпосередньо долучилися до її діяльності як учасники.

Також, на нашу думку, дискусійним $є$ твердження науковців про відсутність окупності НУО, адже, як відомо, у практиці більшості держав світу цим організаціям дозволено здійснювати господарську діяльність, доходи від якої мож- на спрямовувати на досягнення статутної мети ïx діяльності. Відповідно, можна припустити, що НУО, які фрінансуються виключно за рахунок таких доходів, є самоокупними (водночас, варто зауважити, що у такому випадку порушуються інші принципи фінансів НУО, як наприклад, принципи забезпечення фінансової стійкості та залучення фрінансових ресурсів з різноманітних джерел).

Підтримуємо думку про важливість звітування для діяльності НУО, проте, на наш погляд, сумнівним $€$ принцип підзвітності особі-джерелу фінансування, адже часто благодійники бажають залишитися невідомими або ж фінансування характеризується масовістю (наприклад, за допомогою краудфандингового механізму), а тому і звітування перед конкретними особами неможливе.

Т. Ю. Кисельова, С. С. Дзусова та С. В. Фруміна, досліджуючи формування доходів і надходжень НО, наголошують, що цим двом групам фінансового забезпечення діяльності НО притаманні принципово різні принципи формування. Так, на їх думку, доходи НО формуються на основі принципів платності та поворотності, а їх надходження на принципах безоплатності та неповоротності [18, с. 95]. Окрім цього науковиці стверджують, що у процесі формування та використання фінансових ресурсів НУО важливим $є$ принцип їх цільового призначення [18, с. 93]. Погоджуємося із важливістю застосування принципу цільового використання, адже, на нашу думку, він $є$ одним із основоположних принципів, який, власне, відрізняє НО від тих, діяльність яких спрямована на отримання прибутку. Проте, вважаємо дискусійним розділення принципів формування джерел фрінансування цих організацій відповідно до їх поділу на доходи та находження, адже, наприклад, доходи НО від їх господарської діяльності не формуються на основі принципів платності та повернення. Водночас у власних подальших дослідженнях Т. Ю. Кисельова, аналізуючи особливості процесів формування і використання фінансових ресурсів некомерційних організацій в сучасних умовах, вже уточнює, виділяючи три їх основні принципи: неповоротності, безоплатності та цільового використання [17, с. 8]. Такий підхід також вважаємо не до кінця коректним, оскільки НУО у своїй діяльності можуть залучати кошти з будь-яких джерел, не заборонених законодавством. Відповідно, вони можуть отримувати кредитні кошти, залучення яких, як відомо, здійснюється на принципах як платності, так і поворотності.

Н. В. Семенова підкреслює, що специфічне положення фінансів НО підтверджується і принципами організації їх фрінансів, до основних із яких належать такі [21]: 
1. Принцип господарської самостійності передбачає, що НО самостійно визначають напрями своєї діяльності згідно з цілями, заради яких вони створені і які відображені у статуті.

2. Принцип самофрінансування означає, що НО повинні повністю окупати свою діяльність за рахунок власних коштів.

3. Принцип цільового використання означає, що всі кошти, що надійшли в НО витрачаються строго на статутні цілі за затвержденим фрінансовим планом (бюджетом).

4. Принцип роздільного обліку передбачає, що $є$ розмежування коштів цільового фінансування і самостійно зароблених.

5. Принцип забезпечення фрінансових резервів зумовлений поняттям «цільовий капітал» сформованою за рахунок пожертв грошових коштів, частина майна НО, передана нею у довірче управління керуючій компанії для отримання доходу, що використовується для фрінансування статутної діяльності НО.

6. Принцип державного контролю, який проявляється у створенні спеціальних структур, що здійснюють контроль за цільовим використанням коштів і діяльністю НО.

Загалом, на наш погляд, із запропонованими принципами організації фінансів НО можна погодитися, крім останнього, оскільки державний контроль має бути орієнтований на державні кошти та кошти, які мають надходити до бюджетів різного рівня і загальнодержавні позабюджетні фонди.

С. В. Панасенко, досліджуючи принципи та методи управління некомерційними організаціями, серед інших принципів управління ними виділяє і ті, які стосуються безпосередньо їх фрінансів. Такими принципами є [20]:

- принцип забезпечення фрінансової стійкості (пошук та залучення фрінансування з різноманітних джерел);

- принцип відкритості та прозорості використання ресурсів;

- принцип інтенсивного використання всіх можливих ресурсів (як фрінансових, так і людських). Подібного підходу притримується також Р. І. Бунєєва [8, с. 98]. На нашу думку, зазначені науковцями принципи є адекватними для діяльності НУО. При цьому зазначимо, що оскільки предметом дослідження вчених було висвітлення принципів та методів управління некомерційними організаціями загалом, то такий підхід $€$ неповним, оскільки він враховує лише окремі аспекти, пов'язані із управлінням некомерційних організацій, які, на думку вчених, є найважливішими. Саме тому, вважаємо, що даний підхід до виокремлення принципів фрінансів НУО можна використовувати у комплексі з іншими.

Л. У. Сугробова дослідила принципи функціо- нування і методологічних підходів до фрормування і використання цільового капіталу некомерційних організацій, при цьому виділила основні принципи його формування та використання. Хочемо зауважити, що в даному разі мова йде про формування і використання фрінансових ресурсів, адже ті фрінансові ресурси, що знаходяться у розпорядженні НУО, повинні використовуватися на цілі, що передбачені статутами організацій. Науковиця виділяє 6 таких основних принципів, які характеризує як [22, с. 126]:

1. принцип цільового характеру - під яким розуміється, що цільовий капітал некомерційних організацій створюється для реалізації певних цілей, які можуть характеризуватися як вузькою спрямованістю, так і спрямуванням на вирішення важливих проблем соціально-економічного характеру на загальнодержавному чи регіональному рівнях;

2. принцип динамічності - при фрормуванні цільового капіталу передбачається його постійний розвиток відповідно до динамічних змін в економічних умовах функціонування НУО;

3. принцип фрінансової стійкості - забезпечує можливість оперативно, вчасно і в повному обсязі фрінансувати цілі і напрями діяльності НУО;

4. принцип довготривалості - розрахунок на функціонування і досягнення цілей на максимально тривалий період часу;

5. принцип відкритості - для успішної і ефрективної діяльності використання цільового капіталу повинне бути зіставним з відкритою і прозорою діяльністю НУО;

6. принцип соціальної відповідальності - для реалізації суспільної мети в процесі прийняття рішень важливим $\epsilon$ не тільки врахування інтересів організації, але інтересів, цінностей та цілей широких соціальних груп і суспільства загалом.

Розглянувши вищевикладені наукові підходи до виділення та трактування принципів фрінансів НУО, що застосовуються як у передовій міжнародній практиці, так і на пострадянському просторі, хочемо узагальнити, що, на нашу думку, організація та фрункціонування фрінансів ГС повинні здійснюватися згідно із такими принципами:

- законності залучення фрінансових ресурсів та напрямів їх використання;

- неприбутковості;

- цільового спрямування використання фрінансових ресурсів;

- забезпечення фрінансової стійкості ІГС;

- інтенсивного використання всіх можливих ресурсів;

- відкритості та прозорості використання ресурсів;

- внутрішнього контролю за фрінансовими ресурсами; 
- громадського контролю;

- динамічності;

- довготривалості;

- соціальної спрямованості діяльності;

- соціальної відповідальності.

Умовно ці принципи можна поділити на 3 основні групи: принципи першої групи безпосередньо стосуються особливостей діяльності НУО порівняно з комерційними організаціями; принципи другої групи - пов'язані із процесами фоормування та використання фрінансових ресурсів та контролю за ними; принципи третьої групи відображають особливості організації фрінансів ГС відповідно до вимог сучасності (рис. 1).

Такий поділ принципів організації та функціонування фрінансів ГС дає змогу досліднику

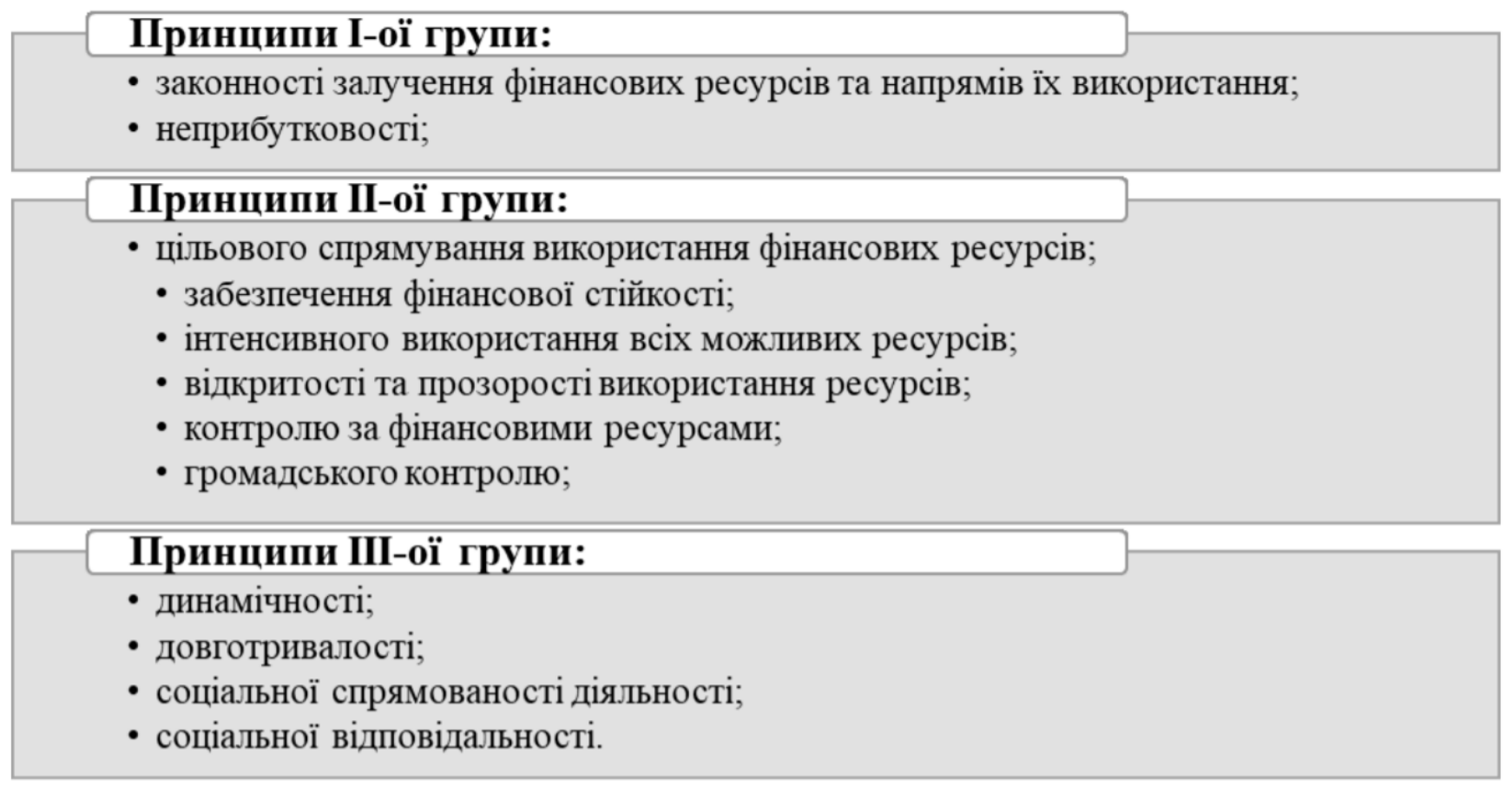

Джерело: побудовано автором

сорормувати теоретичну базу для дослідження особливостей їх функціонування відповідно до основних змістових характеристик, а також ролі, яку вони відіграють чи можуть відігравати у суспільстві.

Висновки. У результаті здійснення критичного аналізу підходів до трактування принципів організації та функціонування ІГС, їх фрінансових аспектів, а також теоретичних підходів до визначення принципів фрінансів НУО, виділено 11 основних принципів організації та фрункціонування фінансів ГС. Всі ці принципи поділяємо на 3 основні групи, які різняться за змістом: принципи першої групи (законності залучення фрінансових ресурсів та напрямів їх використання; неприбутковості) безпосередньо стосуються особливостей діяльності НУО порівняно 3 комерційними організаціями; принципи другої групи (цільового спрямування використання фрінансових ресурсів; забезпечення фрінансової стійкості; інтенсивного використання всіх можливих ресурсів; відкритості та прозорості використання ресурсів; контролю за фрінансовими ресурсами; громадського контролю) - пов'язані із процесами формування та використання фрінансових ресурсів та контролю за ними; принципи третьої групи (динамічності; довготривалості; соціальної спрямованості діяльності; соціальної відповідальності) - відображають особливості організації фрінансів ГС відповідно до вимог сучасного світу. За допомогою такого поділу основних принципів організації та функціонування фрінансів ГС можна дослідити особливості їх функціонування відповідно до основних змістових характеристик, а також ролі (реальної чи потенційної), яку відіграють фінанси ГС у суспільстві та економіці, що може потенційно стати основою для подальших наукових досліджень: теоретичних та практичних у сорері фринансів громадянського суспільства. 


\section{БІБЛІОГРАФІЧНИЙ СПИСОК:}

1. Croissant A., Lauth H., Merkel W. Zivilgesellschaft und Transformation. Ein internationaler Vergleich. Systemwechsel Zivilgesellschaft und Transformation. Opladen: Leske + Budrich, 2000. S. 9-49.

2. Edwards M. Civil society. Cambridge: Polity, 2004. 192 p.

3. Merkel W., Lauth H. Systemwechsel und Zivilgesellschaft. Welche Zivilgesellschaft braucht die Demokratie? Aus Politik und Zeitgeschichte. 1998. Vol. 6 (7). S. 3-12.

4. Paffenholz T., Spurk C. Civil society, civic engagement, and peacebuilding. Social Development Papers. URL: https://documents.worldbank.org/en/publication/documents-reports/documentdetail/822561468142505821/civilsociety-civic-engagement-and-peacebuilding (дата звернення: 31.10.2021).

5. Schade J. Zivilgesellschaft. Eine vielschichtige Debatte. Duisburg: INEF, 2002. URL: https://www.uni-due.de/ imperia/md/content/inef/report59.pdf (дата звернення: 31.10.2021).

6. Tkachuk I. World and national principles of organization, functioning and financing of civil society organizations. Journal of European Economy. 2019. Vol. 18. No 3 (70). https://doi.org/10.35774/jee2019.03.378

7. Балкоева Л. Б. Особенности организации фринансов некоммерческих организаций. Наука через призму времени. 2018. № 7. C. 51-56. URL: https://www.elibrary.ru/item.asp?id=35270440 (дата звернення: 31.10.2021).

8. Бунеева Р. И. Принципы управления, определяющие развитие некоммерческих организаций. Вестник Челябинского государственного университета. 2011. № 6 (221). C. 97-99. URL: https://cyberleninka.ru/article/n/ printsipy-upravleniya-opredelyayuschie-razvitie-nekommercheskih-organizatsiy (дата звернення: 31.10.2021).

9. Василенко Л. І., Зелінський С. В. Фінансове забезпечення діяльності і розвитку громадських організацій. Фінанси України. 2002. № 8. С. 33-39.

10. Вінніков О., Ковриженко Д., Лациба М. та ін. Державне фінансування організацій громадянського суспільства. Як запровадити європейські стандарти? / Укр. незалеж. центр політ. дослідж. Київ: Агентство «Україна», 2010. 224 c.

11. Гаркавенко И. С. Финансы некоммерческих организаций: особенности функционирования. Петербургский экономический журнал. 2013. № 2(2). С. 84-93.

12. Грищенко А. В. Механизм формирования фринансовых ресурсов некоммерческих организаций. Вестник финансового университета. 2014. №4. C. 64-74. URL: https://cyberleninka.ru/article/n/mehanizmy-formirovaniyafinansovyh-resursov-nekommercheskih-organizatsiy/viewer (дата звернення: 31.10.2021).

13. Грищенко А. В. Развитие фринансового обеспечения некоммерческих организаций. Управленческие науки в современном мире. 2016. Т. 1. С. 58-62.

14. Дехтяр Н. А., Люта О. В., Пігуль Н. Г. Фінансовий механізм діяльності суб'єктів господарювання: моногр. Суми: Університетська книга, 2011. 182 с. URL: https://essuir.sumdu.edu.ua/bitstreamdownload/123456789/50128/4/Dekhtiar_Finansovyi_mekhanizm.pdf (дата звернення: 31.10.2021).

15. Ишина И. В., Долина О. Н. Развитие финансов некоммерческих организаций как фрактор социального проресса общества // В сборнике: Современное инновационное общество: динамика становления, приоритеты развития, модернизация: экономические, социальные, философские, правовые, общенаучные аспекты материалы международной научно-практической конференции. 2015. С. 157-160.

16. Кириленко О. П. Міжнародний досвід застосування нетрадиційних методів фрінансування громадських організацій. Науковий огляд. 2015. № 10 (20). С. 21-28.

17. Киселева Т. Ю. Анализ фрормирования и использования финансовых ресурсов некоммерческих организаций в современных условиях. Бухгалтерский учет в бюджетных и некоммерческих организациях. 2016. No 13 (2016). C. 7-17. URL: https://cyberleninka.ru/article/n/analiz-formirovaniya-i-ispolzovaniya-finansovyhresursov-nekommercheskih-organizatsiy-v-sovremennyh-usloviyah-1/viewer (дата звернення: 31.10.2021).

18. Киселева Т. Ю., Дзусова С. С., Фрумина С. В. Формирование денежных доходов и поступлений некоммерческих организаций. Финансы: Теория и Практика. 2015. № 5 (89). С. 87-96.

19. Обушний С. Фінансове забезпечення діяльності політичних партій в Україні: авторефр. дис. ...канд. екон. наук. Київ: 2008. 20 с.

20. Панасенко С. В. Принципы и методы управления некоммерческими организациями. Сборник на учных трудов. Серия «Экономика». 2002. В. 5. URL: http://rcenter.su/upload/iblock/c97/zrtoyacu\%20о\%20aoduyq \%20 djcfhtszsq \%20dru.PDF (дата звернення: 31.10.2021).

21. Семенова Н.В. Место и роль фринансов некоммерческих организаций в развитии гражданского общества. Теория и практика общественного развития. 2009. C. 198-202. URL: http://teoria-practica.ru/rus/files/ arhiv_zhurnala/2009/1/semenova.pdf (дата звернення: 31.10.2021).

22. Сугробова Л. А. Принципы функционирования и методологические подходы к фрормированию и спользованию целевого капитала некоммерческих организаций. Инновации и инвестиции. 2020. №9. URL: https:// cyberleninka.ru/article/n/printsipy-funktsionirovaniya-i-metodologicheskie-podhody-k-formirovaniyu-i-ispolzovaniyutselevogo-kapitala-nekommercheskih/viewer (дата звернення: 31.10.2021).

23. Ткачук I. Фінанси громадянського суспільства. Дис. ... д.е.н. Львів. 2021. 491 c. URL: https://drive.google. com/file/d/1DpuAY3I7ISjrW3Os9W5OL3wOjFe7TSla/view (дата звернення: 31.10.2021).

24. Фрумина С. В., Киселева Т. Ю., Дзусова С. С. Особенности финансового механизма некоммерческих организаций. Вестник Удмуртского университета. 2015. Т. 25, вып. 3. С. 63-70.

25. Pasko O., Chen F., Oriekhova A., Brychko A. \& Shalyhina I. Mapping the Literature on Sustainability Reporting: A Bibliometric Analysis Grounded in Scopus and Web of Science Core Collection. European Journal of Sustainable 
Development. 2021. 10(1), 303-322. https://doi.org/10.14207/ejsd.2021.v10n1p303

26. Shmygol N., Marhasova V., Galtsova O., Solovyov O., Zhavoronok A. Problems of competitive development of industry in Ukraine. European Journal of Accounting, Finance \& Business. 2020.14 (24).

27. Zhavoronok A., Alfimova A. E-commerce: a Bibliographic Analysis. European Journal of Accounting, Finance \& Business. 2021. 25.

28. Zhavoronok A., Kosach I., Duka A., Starchenko G., Myhaylovska O. Socioeconomic viability of public management in the context of European integration processes. Administratie si Management Public. 2020. 35. P. 139-152. https://doi.org/10.24818/amp/2020.35-09

\section{REFERENCES:}

1. Croissant, A., Lauth, H., Merkel, W. (2000). Zivilgesellschaft und Transformation. Ein internationaler Vergleich. Systemwechsel Zivilgesellschaft und Transformation, Opladen: Leske + Budrich, 9-49.

2. Edwards, M. (2004). Civil society. Cambridge: Polity.

3. Merkel, W., Lauth, H. (1998). Systemwechsel und Zivilgesellschaft. Welche Zivilgesellschaft braucht die Demokratie? Aus Politik und Zeitgeschichte, Vol. 6 (7), 3-12.

4. Paffenholz, T., Spurk, C. Civil society, civic engagement, and peacebuilding. Social Development Papers. URL: https://documents.worldbank.org/en/publication/documents-reports/documentdetail/822561468142505821/ civil-society-civic-engagement-and-peacebuilding (дата звернення: 31.10.2021).

5. Schade, J. (2002). Zivilgesellschaft. Eine vielschichtige Debatte. Duisburg: INEF. URL: https://www.uni-due.de/ imperia/md/content/inef/report59.pdf (дата звернення: 31.10.2021).

6. Tkachuk, I. (2019). World and national principles of organization, functioning and financing of civil society organizations. Journal of European Economy, Vol. 18, No 3 (70). https://doi.org/10.35774/jee2019.03.378

7. Balkoeva, L. B. (2018). Osobennosty orhanyzatsyy fynansov nekommercheskykh orhanyzatsyi [Features of the organization of financial non-profit organizations]. Nauka cherez pryzmu vremeny - Science through the prism of time, 7, 51-56. (in Russian). URL: https://www.elibrary.ru/item.asp?id=35270440 (accessed 31.10.2021).

8. Buneeva, R. Y. (2011). Printsipi upravlenyia, opredeliaiushchye razvytye nekommercheskykh orhanyzatsyi [Principles of management that determine the development of non-profit organizations]. Vestnyk Cheliabynskoho hosudarstvennoho unyversyteta - Bulletin of the Chelyabinsk, 6 (221), 97-99. (in Russian). URL: https://cyberleninka. ru/article/n/printsipy-upravleniya-opredelyayuschie-razvitie-nekommercheskih-organizatsiy (accessed 31.10.2021).

9. Vasylenko, L. I., Zelinskyi, S. V. (2002). Finansove zabezpechennia diialnosti i rozvytku hromadskykh orhanizatsii [Financial security of performance and development of community organizations]. Finansy Ukrainy - Finance of Ukraine, 8, 33-39. (in Ukrainian).

10. Vinnikov, O., Kovryzhenko, D., Latsyba, M. (2010). Derzhavne finansuvannia orhanizatsii hromadianskoho suspilstva. Yak zaprovadyty yevropeiski standarty? [State financing of the organization of community support. Yak to propose European standards?]. Kyiv: Ahentstvo «Ukraina». (in Ukrainian).

11. Harkavenko, Y. S. (2013). Finansi nekommercheskykh orhanyzatsyi: osobennosty funktsyonyrovanyia [Finances of non-commercial organizations: features of functioning]. Peterburhskyi эkonomycheskyi zhurnal Petersburg Economic Journal, 2(2), 84-93. (in Russian).

12. Hryshchenko, A. V. (2014). Mekhanyzm formyrovanyia fynansovыkh resursov nekommercheskykh orhanyzatsyi [Mechanism of formation of financial resources of non-commercial organizations]. Vestnyk fynansovoho unyversyteta - Financial University Bulletin, 4, 64-74. (in Russian). URL: https://cyberleninka.ru/article/n/mehanizmyformirovaniya-finansovyh-resursov-nekommercheskih-organizatsiy/viewer (accessed 31.10.2021).

13. Hryshchenko, A. V. (2016). Razvitiye finansovogo obespecheniya nekommercheskikh organizatsiy [Development of financial support for non-profit organizations]. Upravlencheskiye nauki $v$ sovremennom mire Management sciences in the modern world, 1, 58-62. (in Russian).

14. Dekhtiar, N. A., Liuta, O. V., Pihul, N. H. (2011). Finansovyi mekhanizm diialnosti subiektiv hospodariuvannia: monohr [Financial mechanism of business entities: monograph]. Sumy: Universytetska knyha. (in Ukrainian). URL: https://essuir.sumdu.edu.ua/bitstream-download/123456789/ 50128/4/Dekhtiar_Finansovyi_mekhanizm.pdf (accessed 31.10.2021).

15. Ishina, I. V., Dolina, O. N. (2015). Razvitiye finansov nekommercheskikh organizatsiy kak faktor sotsialnogo proressa obshchestva [Development of finance of non-profit organizations as a factor of social progress of society]. $\mathrm{V}$ sbornike: Sovremennoye innovatsionnoye obshchestvo: dinamika stanovleniya. prioritety razvitiya. modernizatsiya: ekonomicheskiye. sotsialnyye. filosofskiye. pravovyye. obshchenauchnyye aspekty materialy mezhdunarodnoy nauchno-prakticheskoy konferentsii - In the collection: Modern innovative society: the dynamics of formation. development priorities. modernization: economic. social. philosophical. legal. general scientific aspects materials of the international scientific and practical conference, 157-160. (in Russian).

16. Kyrylenko, O. P. (2015). Mizhnarodnyi dosvid zastosuvannia netradytsiinykh metodiv finansuvannia hromadskykh orhanizatsii [International awareness of non-traditional methods of financing community organizations]. Naukovyi ohliad - Scientific look,10 (20), 21-28. (in Ukrainian).

17. Kyseleva, T. Yu. (2016). Analiz formirovaniyia i ispolzovanyia finansovykh resursov nekommercheskikh orhanizatsyi v sovremennykh usloviiakh [Analysis of the formation and use of financial resources of non-profit organizations in modern conditions]. Bukhhalterskyi uchet $v$ biudzhetnыkh y nekommercheskykh orhanyzatsyiakh - Accounting in budgetary and non-profit organizations, 13, 7-17. (in Russian). URL: https://cyberleninka.ru/ 
article/n/analiz-formirovaniya-i-ispolzovaniya-finansovyh-resursov-nekommercheskih-organizatsiy-v-sovremennyhusloviyah-1/viewer (accessed 31.10.2021).

18. Kyseleva, T. Yu., Dzusova, S. S., Frumyna, S. V. (2015). Formirovanie denezhnykh dokhodov i postuplenyi nekommercheskikh orhanizatsyi [Formation of monetary incomes and receipts of non-commercial organizations]. Finansi: Teoryia y Praktyka - Finance: Theory and Practice, 5 (89), 87-96. (in Russian).

19. Obushnyi, S. (2008). Finansove zabezpechennia diialnosti politychnykh partii v Ukraini: avtoref. dys. ...kand. ekon. nauk [Financial support of political parties in Ukraine: author. dis. ... cand. econ. science]. Kyiv. (in Ukrainian).

20. Panasenko, S. V. (2002). Printsipy i metody upravleniya nekommercheskimi organizatsiyami [Principles and methods of managing non-profit organizations]. Sbornik na uchnykh trudov. Seriya "Ekonomika» - Collection of academic works. Economics series, B. 5. (in Russian). URL: http://rcenter.su/upload/iblock/c97/zrtoyacu\%200\%20 aoduyq\%20djcfhtszsq\%20dru.PDF (accessed 31.10.2021).

21. Semenova, N. V. (2009). Mesto i rol finansov nekommercheskikh organizatsiy $v$ razvitii grazhdanskogo obshchestva [The place and role of finance of non-profit organizations in the development of civil society]. Teoriya $i$ praktika obshchestvennogo razvitiya - Theory and practice of social development, 198-202. (in Russian). URL: http:// teoria-practica.ru/rus/files/arhiv_zhurnala/2009/1/semenova.pdf (accessed 31.10.2021).

22. Sugrobova, L. A. (2020). Printsipy funktsionirovaniya i metodologicheskiye podkhody $k$ formirovaniyu i spolzovaniyu tselevogo kapitala nekommercheskikh organizatsiy [Principles of functioning and methodological approaches to the formation and use of target capital of non-profit organizations]. Innovatsii i investitsii - Innovation and investment, 9. (in Russian). URL: https://cyberleninka.ru/article/n/printsipy-funktsionirovaniya-i-metodologicheskiepodhody-k-formirovaniyu-i-ispolzovaniyu-tselevogo-kapitala-nekommercheskih/viewer (accessed 31.10.2021).

23. Tkachuk, I. (2021). Finansy hromadianskoho suspilstva. Dys. ... d.e.n. Lviv [Finance of civil society. Dis. ... d.e.n.]. (in Ukrainian). URL: https://drive.google.com/file/d/1DpuAY3I7ISjrW3Os9W5OL3wOjFe7TSla/view (accessed 31.10.2021).

24. Frumina, S. V..Kiseleva, T.Yu..Dzusova, S.S.(2015). Osobennostifinansovogomekhanizmanekommercheskikh organizatsiy [Features of the financial mechanism of non-profit organizations]. Vestnik Udmurtskogo universiteta Bulletin of Udmurt University, 25(3), 63-70. (in Russian).

25. Pasko, O., Chen, F., Oriekhova, A., Brychko, A., \& Shalyhina, I. (2021). Mapping the Literature on Sustainability Reporting: A Bibliometric Analysis Grounded in Scopus and Web of Science Core Collection. European Journal of Sustainable Development, 10(1), 303-322. https://doi.org/10.14207/ejsd.2021.v10n1p303

26. Shmygol, N., Marhasova, V., Galtsova, O., Solovyov, O., Zhavoronok, A. (2020). Problems of competitive development of industry in Ukraine. European Journal of Accounting, Finance \& Business, 14 (24).

27. Zhavoronok, A., Alfimova, A. (2021). E-commerce: a Bibliographic Analysis. European Journal of Accounting, Finance \& Business, 25.

28. Zhavoronok, A., Kosach, I., Duka, A., Starchenko, G., Myhaylovska, O. (2020). Socioeconomic viability of public management in the context of European integration processes. Administratie si Management Public, 35, 139152. https://doi.org/10.24818/amp/2020.35-09 